\title{
The Impact of Intangible Assets Internally Developed on the Market Value of Companies "A Field Study in the Pharmaceutical Companies in Jordan."
}

\author{
Osama Omar Jaara ${ }^{1} \&$ Khalid Abdul Rahman Elkotayni ${ }^{2}$ \\ ${ }^{1}$ Associate professor in Accounting, American university of Madaba, Madaba, Jordan \\ ${ }^{2}$ Prof. Dr. in Accounting, Zarqa University, P.O. Box 132222, Zarqa 13110, Jordan. E-mail: khkotayni@ zu.edu.jo
}

Correspondence: Dr. Osama Omar Jaara, Associate professor in Accounting, American university of Madaba, Madaba, Jordan. E-mail: o.jaara@aum.edu.jo

Received: April 23, 2016

Accepted: May 5, 2016

Online Published: May 19, 2016

doi:10.5430/afr.v5n2p154

URL: http://dx.doi.org/10.5430/afr.v5n2p154

\section{Acknowledgements}

Special thanks to American University of Madaba and Zarqa University in Jordan for supporting this research.

\begin{abstract}
This study aims to investigate the impact of intangible assets internally generated (development costs, and patents) in the market value of pharmaceutical companies in Jordan. The study population of financial employees (Auditors, analysts, accountants) working in six Jordanian pharmaceutical companies, the sample was chosen randomly consisted of 62 financials. The study data were collected through the development of a questionnaire. The results showed that investment in intangible assets strongly affect maximize the market value of Jordanian pharmaceutical companies .It has also shown to maintain the confidentiality of information of manufacturing of patents to conserve the competitive position of the pharmaceutical companies for a long time. The study supports the success of the Jordanian pharmaceutical companies to maximize their competitiveness through development costs and patents.
\end{abstract}

Keywords: Intangible assets, Development costs, Patent costs, Investment, Pharmaceutical companies

\section{Introduction}

The pharmaceutical industry has become as the most important economic sector in Jordan because of its importance in maintaining the human safety and health. For this reason, this sector needs to research and development on a permanent basis for the discovery of patents (new drugs). In addition, to develop these by investing a lot of money. Hence we note the importance of research and development in this area. The patents are the most important intangible assets in the pharmaceutical sector. They play an important role in protecting the rights of the company when making a new drug, which leads to distinguish the company in the market, and access to material returns. With the trend toward e-business of companies and what resulting change in the rules of competition between them in the global markets, it found that the superiority in intangible assets such as the possession of intellectual capital, and patent rights. Through management accounting strategy of intangible assets that are considered appropriate approach to compete in our time. The most important source to bring wealth, and therefore the real company's market value is calculated became requires a comprehensive assessment of tangible and intangible assets alike (Chander, 2010).

The study paper will explain the following issues:

\subsection{Problem of the Study}

Most of companies are facing an overlook a lot for the concept and the importance of intangible assets in pharmaceutical companies, which are generated internally. It is an important revenue and supplier influential in achieving efficient and high value to these industrial companies. The inability to determine the impact of this omission, which makes the market value of the companies, is not a positive effect on profits. These assets is one of the most important resources that will help the company to strengthen its competitive position, where it clearly appeared due to increased competition in the industry in general, and the pharmaceutical industry, in particular in 
Jordan. Resulting to focus on strengthening the market value of the Jordanian pharmaceutical companies through increased attention to intangible assets internally generated in these companies.

Based on the foregoing, the researchers raise the next question and try to answer it later:

- Do intangible assets internally generated affect the market value of the Jordanian pharmaceutical companies?

This question has sub-questions:

1. Does intangible assets generated internally affect (development costs) on the market value of the Jordanian pharmaceutical companies?

2. Do intangible assets generated internally affect (patents) on the market value of the company in the Jordanian pharmaceutical sector?

\subsection{Objectives of the Study}

1. Identify the impact of intangible assets generated internally in the development costs of the market value of the company in the pharmaceutical sector in Jordan.

2. Identify the impact of intangible assets internally generated in the patent on the market value of the company in the pharmaceutical sector in Jordan.

\subsection{The Importance of the Study}

The importance of this study have applied to pharmaceutical companies operating in Jordan, offering a specific contribution to support the results of other studies that have looked at this area. In addition to being, reveal the impact of intangible assets to maximize the market value of these companies in the Jordanian financial market.

\subsection{Research Methodology}

To test the hypotheses of the study and to achieve its goals, the researchers used the inductive approach, through access to previous studies in the literature and thought of accounting and management. As well as scientific research, and articles related to the subject of study. The researchers used the descriptive and analytical approach, and developed a questioner as a tool to test the hypotheses and validated in order to be accepted or rejected.

\subsection{Research Hypotheses}

The hypotheses based on the problem of the study and questions as follows:

$\mathbf{H O}_{1}$ : There is no statistically significant effect of intangible assets (development costs) on the market value of the company at the significance level $\alpha=0.05$.

$\mathbf{H O}_{2}$ : There is no statistically significant effect of intangible assets (patents) on the market value of the company at the significance level $\alpha=0.05$.

\subsection{The Limits of the Study}

Human limits: financial (accountant, auditor, analyst) workers in the surveyed pharmaceutical companies listed at the Amman Stock Exchange.

Location limits: limited study on this topic researched medicines companies listed at the Amman Stock Exchange.

Period limits: the period required to complete the process of study, is through 2016.

\subsection{The Study Model}

$$
\text { Dependent variable Independent variables }
$$

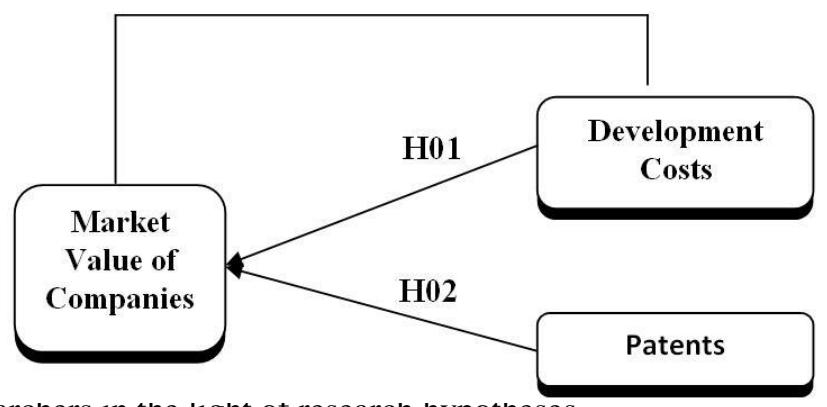

Source: prepared by the researcners in the ilgnt of researcn nypotneses. 
The paper has organized as follows: the next section provides a review of literature and previous studies. Section three deals with Study instruments. Section four presents Results of Statistical analysis and hypothesis testing. Finally, section five presents Conclusions and recommendations.

\section{Literature Review and Previous Studies}

\subsection{Literature Review}

\subsubsection{The Concept of Intangible Assets}

The growing interest in intangible assets in the present day is particularly in determining the contrast between the book value of the company according to the accounting records and the market value of the company significance. It has observed rise in intangible assets and the size of its contribution to the growth of companies during the last two decades.

Abu Nassar (2012, p: 626) has defined intangible assets by International Accounting Standard No. (38), as asset of non-cash determinable but has no physical existence. The standard shows that there are two conditions must met to recognize for intangible asset. These are, company control because of its previous events, such as the purchase or internal development. The second condition is the company's expectation for the future represented by cash flows benefit because of the acquisition of the asset.

While Najem (2010, p. 14) has defined as, intangible assets include benefits or future value. There are others, who define it just as a pretension with future benefits, and do not have a physical or financial shape, it check savings in the cost (Lev, 2001, p189). The intangible assets have been defined as knowledge aspects in business organizations that work to create value for the company based on the capacity of staff, resources and organizations and method of operation, relations with shareholders (Stewart, 1991: p 44). The definition of Intangible assets from the point of Financial Accounting Standards Board (FASB) did not differ from the previous definitions. While Bouteiller has included in the definition of intangible assets the main features of it; where included the intangible assets arising because of past events. It has three main features: it non- physical assets, they are able to produce future economic benefits, and it has legally protected. (Bouteiller, 2002: p2).

The researchers from their point of view defined intangible assets that do not exist significant entity in the company. However, these assets have other properties identified within the framework of the so-called VRIO. Where this framework consist in line with the framework of analysis based on the distinction strategic asset for other assets.

\subsubsection{Types and Classification of Intangible Assets}

Abu Nassar (2012, p. 627) has mentioned that the classification of intangible assets in accordance with IAS 38 as follows:

-Intangible assets that are ownership through separate purchases.

-Intangible assets that are acquired due to the merger in the business environment between the corporate process.

-Intangible assets that are acquired through a government grant.

- Intangible assets that are generated internally.

\subsubsection{Recognition and Measurement}

According to the above, this type of intangible assets also has aspects concerned with the process of the recognition and measurement. It can be divided according to the type of intangible asset generated internally as follows:

1) Goodwill generated internally

Goodwill is one of the most important intangible assets internally generated and most famously. It has seen to it as internally generated an intangible asset that can not be identified alone or separated from the company. It works to increase the market value of the company, thus make a profit of the business, and in order to have the company goodwill. The ability to achieve increased market value by supporting the following actions that lead to:

-Support the efficient management and workers in the field of research and development، reputation، and scientific expertise.

-The development of a distinct and effective advertising campaign.

-A strategic position.

-Customer conservation and service excellence.

-Excellence in production and quality through continuous research and development. 
- The excellent reputation of the company through research and development, and patents.

IAS 38 has prevent the recognition of internally generated goodwill, for the following reasons:

-The determination of the fair value of goodwill is not the requirement for basic recognition and recorded.

- Can not create goodwill costs internally generated reliably measurable.

2) Research and development

International Standard No. 38 has addressed the subject of research and development expenditures were divided it into two steps:

A- Search costs:

The standard shows how to deal with this stage, and its costs. The international standard (38) was not to recognize this stage of research as an intangible asset. It must address the expenses that have been paid during the period as an expense shown in the income statement. This is due to the standard's reason not to recognize the expenses of search, as an intangible asset is the lack of ability of the company to show clearly.

Tamimi highlights (2013, p. 61) to the reasons for non-capitalized expenses of the research are as follows:

-The difficulty of measuring the costs and not checking it will generate probable future benefits.

-Considered the expenses of search time expense will reduce earnings management.

-There is no united way and agreed to measure intangible assets consisting internally. This leads to the reservation to the accounting process for these assets.

- The high uncertainty of revenues and expenses of the search results size.

B- Development costs:

The standard clarify how to recognize the intangible asset generated internally, so when it can be discrimination or limitation for other assets.

3) Patent

It is one of the types of intangible assets internally generated where it is to recognize of the patent as an intangible asset. It has a legal protection, in order to monopolize the manufacture of a particular commodity, and have a limited useful life in order to extinguish the patent by fixed-term calculated.

\subsubsection{The Relationship between Intangible Assets and Company's Market Value}

Several studies have pointed to the existence of a positive relationship between the intangible assets internally generated, and the market value of the company. This is according to meet the conditions for recognition and disclosure, and valuation contained in the accounting standards. Therefore, incorrect treatments to intangible assets generated internally properly; will leads to a lack of presentation in the financial statements of the company. This is because of the result of such intangible assets are difficult to meet the conditions for recognition, evaluation and disclosure. In addition, the accounting treatment also significantly affect the impact on the market value of the company. The reason behind this is that the financial statements do not provide accurate and sufficient information to determine the true value of the business. (Zaghloul, 2002).

1) Research and development, and its relationship to the market value

As mentioned earlier, the intangible assets have an impact on the market value. This is if it has shown and disclosed in the financial reports. The process of research and development are the most important factors that may affect the value of the business. This is because the product development process need to spend large expenses. In addition, to the administration's attention have to draw to this process.

2) The patent and its relationship to the market value

The patent of the important things that distinguish the company from the other. The patent is for the discovery of new drug no one ever discovered. Therefore, it give you the right to use it within the legal protection against any attempt to imitate it. Then it have the monopoly of the manufacture of the product to the person, company or inventor, giving the company a competitive advantage in the market.

\subsubsection{The Concept of Market Value}

Market value was defined from the standpoint of international evaluation criteria as the estimated amount that should be obtained from the exchange process at the date of valuation between what is offered by the buyer and seller agree 
upon. It should be practical without coercion and consent of the two parties (IVS1: 96), and has ever known (virtue, 2009 , p. 26). The value appears in the stock market that is determined by transactions that occur in the stock market. This value varies according to changes in supply and demand and the amount of profits and financial position of the company.

While Sharifi (2009, p. 93) has define the market value as the sale price of the shares on the stock market multiplied by the number of shares subscribed and paid. This value is higher or lower than the nominal value, or book value. There are many definitions, but through what already understand that the market value of the company is a strategic goal of seeking management of veneration, by focusing on increasing the company's share price in the stock exchange (Naimi, 2009 p. 45).

From the perspective of the researchers, the market value has defined as the value of the stock in the financial market multiplied by the number of shares subscribed.

\subsection{Previous Studies}

Dobre Study, (2013), entitled "Intangible assets as a source of competitiveness in the post-crisis economy, the role of brands".

This study aimed to demonstrate the functions of brands as part of the intellectual property and intangible assets. In the context of the economic crisis, provide an overview of the evolution of these jobs before the economic crisis and beyond. Results of the study have shown that brands are an important element of value for consumers and producers. The study recommended the need for attention to the brand as part of intangible assets through its support through social media.

Salameh, et. al., Study, (2013), entitled "Intangible assets and stock price of Jordanian companies: An empirical analysis".

This study aimed to determine the effect of the essential tangible assets and intangible assets on the market value of the assets of the company's value. The statement of the issue of intangible assets in the Jordanian companies assess the role of these assets in the creation of value for the companies. Where the researcher used the way the remaining operating revenue model as an alternative to the basic value-based property rights model for the evaluation of intangible assets. The results of this study showed that intangible assets positively influence the increasing competitiveness of many Jordanian companies; the study recommended the need to understand and grasp the relationship between intangible assets and share price.

Ramirez, et. al. Study, (2012), entitled "Intangible assets and market value of Japanese industries and firms".

The study aimed to clarify the impact of investment in intangible assets on the market value. The study was applied to a sample of public companies and industries of Japan. It test whether there is a suitable between industrial conditions prevailing, and resources companies of the donations with the market value of the company. The benefit of a link and the results of the study showed a positive impact of research \& development in Tobin investment firms. With the highest levels of intangible assets. It recommended that the trend towards intangible assets to maximize the market value of the companies.

Tamimi Study, (2012), entitled "Intangible assets, consisting internally and requirements of financial reporting".

This study aimed to focus on the importance of intangible assets internally generated and its impact on the investment decisions makers. The accounting treatment of intangible assets internally generated facing some problems related to the capitalization of research and development costs and the conservation of IAS 38 on the capitalization of these costs. According to put tough conditions on this element. The study recommended the need to address these problems when the capitalized costs.

Violeta .et al Study, (2011), entitled "the Intangible assets investment characteristics and the accounting treatment".

This study aimed to release recipes investment in intangible assets. The statement of the accounting treatment of intangible assets by accounting standards, and intangible assets as an important source of competitive advantages for the company. The results of the study showed that the company did not take steps to allow for the capitalization of intangible assets internally generated and failed providing the viewpoint of accurate financial position of the entity over the past decades. The study recommended the need to take steps towards the capitalization of intangible assets, and access to information by users.

Adakkoni Study, (2010), entitled "Evaluation methods of measurement and disclosure of the accounting for intangible assets in commercial establishments: a sample of the Sudanese banks study". 
This study aimed to identify the economic nature of the intangible assets and the extent of their relationship-makers might investment and credit decisions. The results of the study showed that the instability of the use of methods of measurement and disclosure of intangible assets. The users do not trust it making financial statements. The study recommended the need for greater disclosure of intangible assets in the financial statements, a specific binding measurement and disclosure of intangible assets ways, in addition to the continuation of installations using a single policy for the measurement of disclosure of intangible assets.

Basihel Study, (2010), titled "Impact of intellectual capital evaluated to maximize the value of the company's application in Saudi industrial companies".

This study aimed to show the difficulties facing the process of valuing intangible assets such as intellectual capital, in addition to trying to show the importance of intellectual capital as an asset is a tangible role in maximizing the value of the company. The study revealed the existence of an agreement on the importance of intellectual capital and the existence of a relationship between intellectual capital to develop and expand the market value of the company.

The study recommended that the preparation of an independent list for the disclosure of intellectual capital of the company components, and the need for attention to the head of intellectual capital as an asset is tangible because of its importance in maximizing the company's value.

\section{What Distinguishes This Study?}

Previous studies focused on studying the disclosure of intangible assets from the point of accounting theory and investment in India, the market value of the pharmaceutical industry in Japan and researched in this area in the importance of intellectual capital as an asset is intangible, but this study has been in Jordan. Intangible assets have studied internally generated from the standpoint of research and development costs and patent. He did not eat yet another study that took place in Jordan, in addition to posing scientific research efforts in this area.

\section{Study Instrument}

After the completion of the study to determine the problem questions and hypotheses, the researchers prepared a questionnaire study. It developed to cover all variables model study, which included a questionnaire study in its final form to the following parts:

\subsection{Study Instrument Scale}

Five points Likert scale has been selected, for being one of the most metrics used to measure the opinions and responses, due to its ease of understanding, indicates where the study sample under test for the extent of their agreement for each paragraph of the questionnaire as follows:

\begin{tabular}{cccccr}
\hline Description & \multicolumn{5}{c}{ Description rating Likert scale } \\
\hline Answer & Strongly Disagree & Disagree & Not sure & Agree & Strongly Agree \\
The answer code & 1 & 2 & 3 & 4 & 5 \\
\hline
\end{tabular}

A scale has adopted to measure of the degree evaluation of the study sample with the principles of accounting information. It has divided into three levels. Where the calculated cut-off grade and by dividing the product of the difference between the highest value of the scale (5) and the lowest value in it (1) at three levels, namely, that the cut-off grade are as follows: $\{(5-1) \div 3=1.33\}$.

Thus, the three levels as follows:

A - Low degree of agreement (1 - 2.33).

B - The degree of agreement Medium (2.34 - 3.67).

C - A high degree of agreement (3.68 - 5).

\subsection{Study Population and Samples}

The study population consist of Financial Officer (Auditor, analyst and accountant) working in the pharmaceutical companies. It has been selected random sample of 62 individuals working in companies in the following names: Dar Al Dawa, Jordan to produce the medicine, the Middle East pharmaceutical, Al-Hayat Pharmaceutical Industries, the Arab Center for Pharmaceutical Industries, and Philadelphia for the pharmaceutical industry.

\subsection{Instrument Validity and Test of Questionnaire}

After researchers finished the initial design of the questionnaire, in order to ensure its relevance to collect the required data. It has subjected to test the honesty validity in order to ensure that the measurement tool to measure 
precisely and clearly defined concept and not any other concept. Where the questionnaire has presented to a group of arbitrators, professors in scientific methodology, and in management science in general, and some practitioners, providing them with the problematic of the study was to apprise them. The researcher asked everyone to express an opinion about the clarity of the questions and phrases suitability for the purposes of the study. In the light of the observations and suggestions of arbitrators' specialists, it has been the adoption of the paragraphs, which got an approval rating exceeded $(90 \%)$ by the arbitrators.

\subsection{Instrument Reliability}

To check the reliability of study tool, the researchers were using Cronbach's Alpha instrument variables reliability coefficients (to measure the internal consistency of the questionnaire paragraphs). The percentage of stability of the instrument overall was $(95 \%)$, which is very high in order to approve study results, the mean percentage that the internal consistency of the vertebrae high. Since the acceptable percent to generalize Humanities and Social Research results are $(60 \%)$ or more, as shown in table (1) below:

Table 1. Stability Study Tool

\begin{tabular}{|c|c|c|}
\hline No. & Variables & $\begin{array}{l}\text { The correlation } \\
\text { coefficient }\end{array}$ \\
\hline 1 & $\begin{array}{l}\text { The impact of intangible assets internally generated } \\
\text { (development costs) on the market value of the company }\end{array}$ & $92 \%$ \\
\hline \multirow[t]{2}{*}{2} & $\begin{array}{l}\text { The impact of intangible assets internally generated (patent } \\
\text { costs) on the market value of the company }\end{array}$ & $\mathbf{8 8 \%}$ \\
\hline & Total percentage & $95 \%$ \\
\hline
\end{tabular}

\subsection{Statistical Techniques}

The researchers from the process of collecting data on variables model study entered the data for Computer -program for extracting statistical results needed. It was drawing on some statistical methods available in software packages Statistical Social Sciences (SPSS), in order to process the data that have obtained through the study field of the surveyed sample; specifically the researcher used statistical methods the following:

1- Cronbach's alpha coefficient: it used to test the reliability tool to study under which the data are collected. In other words, it used to test internal consistency of the paragraphs of the questionnaire.

2- Frequencies and percentages: they used to identify the characteristics of the study sample.

3- Mean: it used to identify the level of severity of the answer to the sample of the study.

4- Standard deviation: it used to determine the dispersion of the study sample answers from the values of the arithmetic average.

5- T Test: This test was used to determine the intangible assets internally generated affect the market value of the Jordanian pharmaceutical companies.

\section{Results of Statistical Analysis and Hypothesis Testing}

\subsection{Results of Statistical Analysis}

As shown in Table (2), the mean of the effect of intangible assets internally generated on the market value of the companies surveyed were generally high. That the development costs capitalization and disclosure, as well as spending on new product development was the impact on increasing the market value or maintain market share weak. While the researchers concluded that as a result of strategic management methods in support of research and development leading to the generation of intangible assets internally. Other findings that information on manufacturing is considered a competitive advantage for pharmaceutical companies and enhance their profits. 
Table 2. study the effect of variables on the market value

\begin{tabular}{|c|c|c|c|c|}
\hline Variables & $\begin{array}{l}\text { Influence } \\
\text { degree }\end{array}$ & Significance & SD & Mean \\
\hline $\begin{array}{l}\text { The impact of intangible assets internally } \\
\text { generated (development costs) on the market } \\
\text { value of the company }\end{array}$ & High & 1 & 0.49 & 3.88 \\
\hline $\begin{array}{l}\text { The impact of intangible assets internally } \\
\text { generated (patent costs) on the market value } \\
\text { of the company }\end{array}$ & High & 2 & 0.50 & 3.79 \\
\hline Total impact & High & - & 0.495 & 3.835 \\
\hline
\end{tabular}

\subsection{Test Hypothesis}

In order to test the hypotheses of the study the answers of study sample have subjected to (t) test at the level of (0.05) and pursuant to the following decision rule for this test:

Reject the hypothesis of nihilism if (t) is greater than the calculated value and equal (2), or if the level of significance $(\alpha \leq 0.05)$. In addition, accept the hypothesis of nihilism if the value of $(t)$ is smaller than the calculated value and equal to (2) or if the level of significance $(\alpha>0.05)$. According to that, the results of hypothesis are as follows:

4.2.1 Test of First sub-hypothesis $\left(\mathrm{HO}_{1}\right)$

H0 $0_{1}$ : There is no statistically significant effect of intangible assets (development costs) on the market value of the company in the pharmaceutical sector in Jordan at the significance level $\alpha=0.05$.

The researchers test (t) the statistical sample and one, which results, appear in the table (as follows):

Table 3. Test (T) results to one sample test first sub-hypothesis

\begin{tabular}{lllccll}
\hline No. & Mean & SD & T-test & Degrees of freedom & Significance Level & Results \\
\hline 57 & 3.88 & 0.49 & 13.44 & 56 & 0.0000 & Reject
\end{tabular}

Based on the results in the table above, therefore, rejected the hypothesis of nihilism, and accept alternative hypothesis, namely that "intangible assets generated internally affect (development costs) on the market value of the company in the pharmaceutical sector in Jordan".

\subsubsection{Test of Second sub-hypothesis $\left(\mathrm{HO}_{2}\right)$}

$\mathbf{H O}_{2}$ : There is no statistically significant effect of intangible assets (patents) on the market value of the company at the significance level $\alpha=0.05$.

The researchers test $(\mathrm{t})$ the statistical sample and one, which results, appear in the table (as follows):

Table 4. Test (T) results to one sample test second sub-hypothesis

\begin{tabular}{lllccll}
\hline No. & Mean & SD & T-test & Degrees of freedom & Significance Level & Results \\
\hline 57 & 3.79 & 0.50 & 11.99 & 56 & 0.0000 & Reject
\end{tabular}

Based on the results in the table above, therefore, rejected the hypothesis of nihilism, and accept alternative hypothesis, namely that "intangible assets generated internally affect (patent) on the market value of the company in the pharmaceutical sector in Jordan".

\section{The Conclusions and Recommendations}

\subsection{Conclusions}

-The study confirmed the presence of a noticeable effect of intangible assets internally generated on the market value for pharmaceutical companies in Jordan, largely due to the management of pharmaceutical companies capitalized R \& D expenses to generate intangible assets which will reflect positively on the market value of the companies and increase their competitiveness in the Jordanian and Arab market and this result agrees with the study (Salameh, 2013) and it did not agree with the study (Ramirez, 2012).

-The study confirmed that the investment in patents has significantly no effect on the generation of intangible assets in companies and increase their competitiveness in the Jordanian market and the Arab and maximize their market value. This is consistent with a study (Bishops 2007) and (Tamimi: 2012). 
-This study shows that the patent costs included in the annual reports have little effect on increasing the market value of the company.

-The study pointed out that there is no direct impact of the costs of patents and increase the market value of the company.

- To maintain the confidentiality of information processing patents maintains the competitive position of the pharmaceutical companies.

\subsection{Recommendations}

1- There is a need to increase spending on drug companies owning patents, its ability to increase the market value of these companies.

2- There is a need to develop a strategy for the expenses patents, and put it within the company's budget, to support the increased market value of the company.

3- Capitalized development costs and disclosed.

4- The companies need to develop an accounting framework for measuring fair value, which costs are spent on intangible assets that are generated internally.

5- The allocation of funds to invest in existing products owned by the company to develop and improve it.

6- To establishment of a strategic alliance between the Jordanian pharmaceutical companies to maximize the value of intangible assets in the international market competitiveness.

\section{References}

Abdel Moneim, Osama. (2010). intellectual capital and its impact on the industrial businesses-case Jordanian garments company study, unpublished, Jordan.

Abdullah, Abdul Qadir. (1995). the factors determining the price of shares contribute to the Kingdom of Saudi Arabia. Al-Yarmouk Research Journal, 11(1).

Abu Nassar, Mohammed \& Hamidat, Juma. (2012). international accounting standards and financial reporting Theoretical and practical aspects -, Third Edition, Amman: Dar Wael for Publishing and Distribution.

Adakkoni, Abdul Gayoom. (2010). evaluating methods of measurement and disclosure of the accounting for intangible assets in commercial establishments, Master Dissertation, Sudan.

Alboukta, Abraham \& Dawes, Mohammed. (2006). the patent indicator of competitive of economics - Algeria and the Arab States. a Researcher Journal number 4, and the University of Ouargla, Algeria.

Al-Naimi, Adnan Tayeh \& Al-Tamimi, Arshid. (2009). advanced financial management, Amman: Dar Yazouri scientific publication and distribution.

Assaad, Alaa Mustafa. (2013). accounting standards and changes in the contemporary business environment. Journal of Baghdad College of Economic Sciences, Volume V College Conference.

Barajneh, Amjad Ibrahim. (2009), the relationship between the distribution of profits and all of the market value and the book circulating in Palestine Exchange shares test, Master Dissertation, the Islamic University of Gaza.

Barney, J.B. (2002). Gaining and sustaining competitive advantage, Prentice-Hall, Inc, Upper Saddle River.

Basihel, Dania Ahmad. (2010). the impact of intellectual capital evaluated to maximize the value of the company's application in Saudi Industrial companies, Master Dissertation, King Abdul Aziz University, Saudi Arabia.

Bouteiller, Christophe. (2002). The Evaluation of Intangibles: advocating for an option based approach, Hamburg, August.

Boxana, Rashid Onasima, \& Ookel Walorabi, Hamza. (2010). the historical cost between criticism and support under the direction of international accounting standards towards the fair market value. University Center Valley, Algeria.

Chander, S \& Mehra, V. (2010). Disclosure of Intangible Assets in Indian drugs and pharmaceutical industry, Guru Nanak Dev University, India.

Dobre, Ana. (2013). Intangible Assets as a source of competitiveness in the post-crisis economy-the role of brand, National Institute of Statistics, Bucharest. 
Fadela, Zawawi. (2009). the financing institution according to the new economic mechanisms working Algeria-case study to Sonlgar Foundation, Master Thesis, University of Boumerdes, Algeria.

Fayoumi, Ahmad. (2010). the effect of intangible assets in achieving competitive advantage in light of the adoption of standards of total quality management, Master Thesis, University of the Middle East, Jordan.

Green, R ,Berk, J \& Naik, V. (1998). Valuation and return dynamics of new ventures, Oxford Journals.

Habashneh, Fadel, Shahatit, Mohammed, Bdour, Jaber \& Ammarin, Zena. (2014). the factors affecting the stock market price at the Amman Stock Exchange during the period from 1984 to 2011, Amman, Jordan.

IVS 1, Market Value Basis of Valuation, Seventh Edition.

Johanson, M, Martensson, M \& Skoog, M. (2001). Measuring to understand Intangible performance drivers. The European Accounting Review, 10(3). http://dx.doi.org/10.1080/09638180126791

Khaddah, Hossam El-Din \& al-Abadi, Isa. (2005). the relationship of each of the accounting earnings and cash flows to equity market value of the shares, Oman. Administrative Science Studies, 32(1).

Lev, B. (2001). Intangibles: Management, Measurement and Reporting, Brooning Institute press, Washington.

Lev, B \& Daum, J. (2004). the dominance of intangible assets: consequences for enterprise management and corporate reporting, New York University.

Malhotra, A. (2007). Factors affecting share price, Ezine Articles.

Matarneh, Abdelwahab. (2007). intangible investments and their impact on the overall cost of capital in Jordanian companies for the manufacture of drugs and chemicals, PhD Thesis, Amman Arab University for Graduate Studies, Jordan.

Najim, Najim of Aboud. (2010). Administration UN intangible Manage of non-measure, Amman: Dar Yazouri scientific publication and distribution.

Ramirez, P.G \& Hachiya, T. (2012). Intangible assets and market value of Japanese industries and firms, Tokyo, Japan.

Saleh, Ahmed. (2009). intellectual capital, measurement methods and techniques to maintain it, the Arab Organization for Administrative Development, Cairo.

Salameh, A \& Bashir, H. (2013). Intangible assets and stock price of Jordanian companies: an empirical analysis. European Journal of Business and Social Sciences.

Selvon, M. (2008). How liabilities assets ratio determines financial status, Ezine Articles.

Sharifi Nazem \& al-Amiri, Saud. (2009). Advanced Accounting in the theoretical foundations and companies to calculate the value of scientific companies, Amman: Dar Zahran for publication and distribution.

Stewart, T. (1997). Intellectual Capital: the new wealth of organization, Double Day press, New York.

Stewart, T \& Thomas, A. (1991). Brainpower, Fortune, 3.

Tai, Hamid \& Al-Alaq, Bashir. (2008). product development and pricing, Amman: Dar Yazouri scientific publication and distribution.

Tamimi, Abbas \& Al-Saad, Abdul-Hussein. (2013). intangible assets, consisting internally and requirements of financial reporting, Journal, Iraq, the tenth volume.

Violeta, S \& Mariana, P. (2011). The Intangible assets investments characteristics and the accounting treatment, West University of Timisoara, Romania.

Xu Ye, Wang Lijuan. (2010). Empirical analysis of macroeconomic factors affecting the stock price, Shijiazhuang University of Economics.

Zaghloul, Joda. (2002). a proposed framework for intellectual assets and reinforcing them in the economic environment (banking). Scientific journal for Trade and Finance, Trade College, Tanta University, Volume 2, Issue 2. 